\title{
Effects of Dietary Protein and Starch on Intake, Milk Production, and Milk Fatty Acid Profiles of Dairy Cows Fed Corn Silage-Based Diets
}

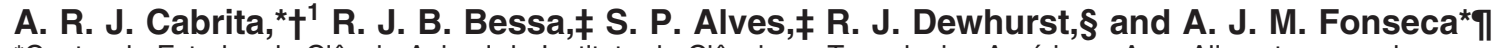 \\ ${ }^{*}$ Centro de Estudos de Ciência Animal do Instituto de Ciências e Tecnologias Agrárias e Agro-Alimentares, and \\ †SAECA, Faculdade de Ciências, Universidade do Porto, Campus Agrário de Vairão, Rua Padre Armando Quintas, \\ 4485-661 Vairão VC, Portugal \\ łDepartamento de Nutrição Animal, Estação Zootécnica Nacional, Instituto Nacional de Investigação Agrária e Pescas, Fonte Boa, \\ 2005-048 Vale de Santarém, Portugal \\ $\S$ Agriculture and Life Sciences Division, Lincoln University, Canterbury, New Zealand \\ ףInstituto de Ciências Biomédicas de Abel Salazar (ICBAS), Universidade do Porto, Campus Agrário de Vairão, Rua Padre Armando Quintas, \\ 4485-661 Vairão VC, Portugal
}

\section{ABSTRACT}

Feed intake, milk production, and milk fatty acid profiles of dairy cows fed corn silage-based diets with different protein and starch concentrations were measured in a 3-period experiment in a changeover design using 12 Holstein cows. Each experimental period lasted for $3 \mathrm{wk}$. The diet fed as a total mixed ration consisted of $45 \%$ corn silage, $5 \%$ coarsely chopped wheat straw, and $50 \%$ concentrate, on a dry matter (DM) basis. The 4 treatments, formulated to be isoenergetic and to differ in concentrations of dietary crude protein (CP) and starch (DM basis), were as follows: low CP and low starch (LPLS; 14\% CP and 15\% starch), low CP and high starch (LPHS; 14\% CP and 25\% starch), high CP and low starch (HPLS; 16\% CP and 15\% starch), and high CP and high starch (HPHS; 16\% CP and 25\% starch). The LPLS treatment led to lower DM intake, milk yield, milk protein concentration, and milk lactose yield, probably due to a shortage of both rumen-degradable protein supply to rumen microbes and glucogenic nutrients to the animal. There were no differences between protein-rich diets and LPHS, suggesting that this diet satisfied the rumen-degradable protein requirements of rumen microbes and did not limit feed intake, and the increased supply of glucogenic nutrients spared AA so that the nutrient requirements of mid lactation dairy cows were met. Further increases in CP concentration increased plasma urea concentration and resulted in decreased efficiency of conversion of dietary $\mathrm{N}$ into milk N. Milk fatty acid profiles were affected by starch and protein supply, with starch having the largest effect. Additionally, increasing dietary starch concentration decreased the apparent transfer of dietary polyunsaturated fatty acids to milk, suggesting

Received June 14, 2006.

Accepted October 12, 2006.

${ }^{1}$ Corresponding author: rita.cabrita@mail.icav.up.pt an increased channeling of fatty acids to adipose tissue. The results further suggest that $\mathrm{C}_{15: 0}$ and $\mathrm{C}_{17: 0}$ are synthesized de novo in animal tissues.

Key words: dairy cow, dietary protein, dietary starch, milk fatty acid

\section{INTRODUCTION}

Current feeding standards for dairy cows focus on protein as a nutrient for both rumen microbes and the animal (NRC, 2001). However, some studies report high DMI and milk production from cows fed diets with protein concentrations that exceed theoretical requirements (Cunningham et al., 1996). Nevertheless, feeding dairy cows excess protein contributes to environmental $\mathrm{N}$ pollution (Kebreab et al., 2002) and can result in unnecessary feeding expenses due to the high costs of protein sources.

The continued response of dairy cows to relatively high protein diets could be mediated by glucogenic precursor supply, among other things. Increasing amounts of either postruminal glucose or ruminal propionic acid is recognized as a method to improve milk and protein yield (Lemosquet et al., 2004) by reducing the use of some AA for gluconeogenesis-the spared AA being available to the mammary gland for the synthesis of milk protein.

Although postruminal glucose (Hurtaud et al., 2000) and ruminal propionic acid (Huhtanen et al., 1998) have similar general effects on milk composition (increased milk protein yield and decreased milk fat concentration and yield), they have different effects on milk fatty acid composition. Increased propionic acid is associated with similar decreases across all even-chain fatty acids. However, increased glucose supply is associated with a linear decrease in the production of even short- and long-chain fatty acids and an increase in the production of medium-chain fatty acids (Rigout et al., 2003). A concomitant increase of plasma insulin has been impli- 
cated (glucogenic-insulin theory) in the preferential channeling of nutrients to adipose tissue, resulting in a shortage of nutrients at the mammary gland and, thus, milk fat depression (Brockman and Laarveld, 1986). Several studies (McGuire et al., 1995; Griinari et al., 1997) with the hyperinsulinemic-euglycemic clamp technique observed no effect on milk fat yield despite large changes in insulin concentrations. However, the inconsistent results on the role of insulin in milk fat depression led Griinari et al. (1997) to suggest that the decrease in milk fat synthesis and the higher net energy intake typically associated with diets that depress milk fat would put the cow in a more positive energy balance.

The objective of this experiment was to evaluate the effects of dietary protein and starch on intake and milk production of dairy cows fed corn silage-based diets. Results could contribute to the development of feeding strategies that decrease the potential environmental pollution of dairy farms and increase the utilization of cereal grains. Additionally, dietary effects on milk fatty acid profiles were investigated to investigate mechanisms of milk fat depression.

\section{MATERIALS AND METHODS}

The feeding trial was conducted at the Dairy Unit of the Direç̧ão Regional de Agricultura do Entre-Douro e Minho (DRAEDM) of the Ministry of Agriculture (Paços de Ferreira, Portugal) from October to December 2004 .

\section{Design, Diets, and Management}

Twelve multiparous [parity number $3.3(\mathrm{SD}=1.2)$ ] Holstein cows averaging $631 \mathrm{~kg}$ of $\mathrm{BW}(\mathrm{SD}=59.8), 77$ DIM (SD = 15.6), and $39 \mathrm{~kg}$ of milk/d $(\mathrm{SD}=5.3)$ were used. Cows were grouped according to milk production, parity, and DIM and randomly assigned to dietary treatment sequences in an incomplete changeover design (three $4 \times 4$ Latin squares with the last period omitted). Each experimental period lasted for 3 wk. Animals were housed and individually fed in a tie-stall barn and had continuous access to water. Diets contained (DM basis) $45 \%$ corn silage, $5 \%$ coarsely chopped wheat straw, and 50\% concentrate. The whole-crop corn silage was prepared during early September 2004, harvested with a precision-chop harvester with a roller mill (Claas 690 SL model, Claas Ltd., Harsewinkel, Germany) at a theoretical chop length of $5.0 \mathrm{~mm}$, and ensiled in a bunker silo without the use of a silage additive. The silo was open after 6 wk. The 4 treatments, formulated to be isoenergetic and to differ in concentrations of dietary CP (14 and 16\%; DM basis) and starch (15 and 25\%; DM basis), were 14\% CP and
Table 1. Ingredient composition of the dietary treatments

\begin{tabular}{|c|c|c|c|c|}
\hline \multirow[b]{2}{*}{ Ingredient, $\%$ of DM } & \multicolumn{4}{|c|}{ Treatment $^{1}$} \\
\hline & LPLS & LPHS & HPLS & HPHS \\
\hline Corn silage & 45.00 & 45.00 & 45.00 & 45.00 \\
\hline Wheat straw & 5.00 & 5.00 & 5.00 & 5.00 \\
\hline \multicolumn{5}{|l|}{ Concentrate mixture $^{2}$} \\
\hline Corn grain & - & 14.60 & - & 14.60 \\
\hline Citrus pulp & 18.60 & 4.75 & 13.86 & - \\
\hline Corn gluten feed & 7.50 & 7.50 & 7.50 & 7.50 \\
\hline Soybean meal & 5.45 & 4.67 & 10.20 & 9.42 \\
\hline Sunflower meal & 14.50 & 14.50 & 14.50 & 14.50 \\
\hline Hydrogenated fat $^{3}$ & 0.76 & 0.25 & 0.76 & 0.25 \\
\hline Molasses & 1.25 & 1.25 & 1.25 & 1.25 \\
\hline $\mathrm{CaCO}_{3}$ & 0.39 & 1.04 & 0.55 & 1.21 \\
\hline Dicalcium phosphate & 0.28 & 0.17 & 0.11 & - \\
\hline Salt & 0.27 & 0.27 & 0.27 & 0.27 \\
\hline Sodium bicarbonate & 0.45 & 0.45 & 0.45 & 0.45 \\
\hline Magnesium oxide & 0.28 & 0.28 & 0.28 & 0.28 \\
\hline Mineral-vitamin premix & 0.27 & 0.27 & 0.27 & 0.27 \\
\hline
\end{tabular}

${ }^{1}$ Diets are named according to the level [low $(\mathrm{L})$ or high $\left.(\mathrm{H})\right]$ of dietary $\mathrm{CP}(\mathrm{P})$ and starch $(\mathrm{S})$ concentrations (\% of $\mathrm{DM})$, respectively: LPLS $=14 \% \mathrm{CP}$ and $15 \%$ starch; LPHS $=14 \% \mathrm{CP}$ and $25 \%$ starch; $\mathrm{HPLS}=16 \% \mathrm{CP}$ and $15 \%$ starch $; \mathrm{HPHS}=16 \% \mathrm{CP}$ and $25 \%$ starch

${ }^{2}$ Concentrate mixtures were prepared in a single batch by Cevargado, Alimentos Compostos, LDA, Arcos, Portugal.

${ }^{3}$ Hydrogenated palm oil (Vetagri Alimentar SA, Cantanhede, Portugal). 1 to $2 \% \mathrm{C}_{14: 0}, 55$ to $60 \% \mathrm{C}_{16: 0}$, and 40 to $45 \% \mathrm{C}_{18: 0}$; Iodine index: $8 \%$ maximum; Melting point: $53^{\circ} \mathrm{C}$.

${ }^{4}$ Contained 2,525,000 IU/kg of vitamin A, 500,000 IU/kg of vitamin $\mathrm{D}_{3}, 4,000 \mathrm{mg} / \mathrm{kg}$ of vitamin E, $106 \mathrm{mg} / \mathrm{kg}$ of Co, $800 \mathrm{mg} / \mathrm{kg}$ of $\mathrm{Cu}$, $5,000 \mathrm{mg} / \mathrm{kg}$ of Fe, $155 \mathrm{mg} / \mathrm{kg}$ of I, $23,040 \mathrm{mg} / \mathrm{kg}$ of Mn, $76 \mathrm{mg} / \mathrm{kg}$ of Se and $40,250 \mathrm{mg} / \mathrm{kg}$ of $\mathrm{Zn}$.

15\% starch (low protein, low starch; LPLS), $14 \% \mathrm{CP}$ and 25\% starch (low protein, high starch; LPHS), 16\% CP and 15\% starch (high protein, low starch; HPLS), and 16\% CP and 25\% starch (high protein, high starch; HPHS). The different dietary protein and starch concentrations were achieved mainly by increasing soybean meal in the high-protein diets and by substituting corn grain for citrus pulp in the high-starch diets (Table 1). To be isoenergetic, the low-starch diets had a higher inclusion of hydrogenated fat. The concentrate mixtures were prepared in a single batch by a compound feed manufacturer (Cevargado, Alimentos Compostos, LDA, Arcos, Portugal). The raw materials were ground in a hammer mill with a $3.0-\mathrm{mm}$ screen and steampelleted ( $4.5 \mathrm{~mm}$ diameter).

Diets were fed as a TMR for ad libitum intake, with fresh feed offered twice a day $(0800$ and $1630 \mathrm{~h})$. The troughs were cleaned out each morning and orts collected and weighed throughout the experiment. Samples of corn silage, wheat straw, concentrates, and orts were sampled 3 times/wk and, after oven DM determination, were composited by week. Feed offered was adjusted each week to produce weighbacks of about $10 \%$ of amounts fed. Cows were milked twice daily at 0730 and $1700 \mathrm{~h}$. 
Milk production was measured throughout the experimental period. Milk was sampled at both milkings on 2 consecutive days during the last week of each experimental period, and proportional composites were analyzed for fat, protein, and lactose (AOAC, 1990; Milkoscan 133, Foss Electric, Hillerød, Denmark). Milk fat was isolated from individual milk samples, collected on the last day of milk sampling, by centrifugation for 15 min at $822 \times g$, and then was immediately stored at $-15^{\circ} \mathrm{C}$ until fatty acid analysis. Blood samples were collected into heparinized tubes from the jugular vein of each cow at $3 \mathrm{~h}$ after the morning feeding on the same day as milk fatty acid sampling. Samples were immediately centrifuged at $822 \times g$ for $10 \mathrm{~min}$ and the plasma stored at $-15^{\circ} \mathrm{C}$ before analysis for glucose, urea, total proteins, and insulin. Cows were weighed at the same time of the day on the final day of each period. Maximum and minimum daily barn temperatures were recorded throughout the experiment.

\section{Chemical Analysis}

Samples of corn silage, wheat straw, concentrates, and orts sampled during the last week of each experimental period were submitted for chemical analysis. The $\mathrm{pH}$ of corn silage was determined in fresh samples with a pH electrode (No. 209811250, Ingold, MettlerToledo International Inc., Columbus, $\mathrm{OH}$ ). Ground samples $(1 \mathrm{~mm})$ were analyzed for ash (AOAC; 1990, method 942.05) and Kjeldahl N (AOAC, 1990; method 954.01). Crude protein was calculated as Kjeldahl $\mathrm{N} \times$ 6.25. Neutral detergent fiber, $\mathrm{ADF}$, and acid detergent lignin (ADL) were determined by the detergent procedures of Van Soest et al. (1991) and Robertson and Van Soest (1981), with $\alpha$-amylase being added, except for wheat straw, during NDF extraction; sodium sulfite was not added. Neutral detergent fiber was expressed without residual ash. For concentrate mixtures, NDF, $\mathrm{ADF}$, and $\mathrm{ADL}$ were determined sequentially. Total sugars were determined by an official Portuguese standard method (Norma Portuguesa-1785, 1986) based on the Luff-Schoorl methodology (Acker, 1967), after extracting sugars with an ethanol solution. Phosphorus and $\mathrm{Ca}$ were determined respectively by gravimetric and volumetric procedures described by official Portuguese standard methods (Norma Portuguesa-873, 1997; Norma Portuguesa-1786, 1985, respectively). Starch was analyzed on finely ground samples (0.5-mm screen) using the method described by Salomonsson et al. (1984).

Fatty acid methyl esters of feed lipids were prepared by a one-step extraction transesterification procedure using toluene, according to Sukhija and Palmquist (1988). The internal standard was heptadecanoic acid.
For milk fatty acids analysis, $200 \mathrm{mg}$ of milk fat layer were weighed into culture tubes, and milk lipids were extracted according to the procedure of Folch et al. (1957), using a dichloromethane and methanol (2:1) solution instead of the chloroform and methanol (2:1) solution (Carlson, 1985). Solvents were then evaporated under nitrogen, and fatty acid methyl esters were prepared by base-catalyzed transesterification with sodium methoxide (Christie, 2004). Fatty acid methyl esters were analyzed using an HP6890 gas chromatograph (Agilent Technologies Inc., Palo Alto, CA) equipped with a flame-ionization detector and a fusedsilica capillary column (CP-Sil 88, $100 \mathrm{~m} \times 0.25 \mathrm{~mm}$ $\times 0.20 \mu \mathrm{m}$, Chrompack CP 7489, Varian Inc., Walnut Creek, CA). The carrier gas was helium and the split ratio was $1: 50$. The injector temperature was $250^{\circ} \mathrm{C}$, and detector temperature was $280^{\circ} \mathrm{C}$. The initial oven temperature of $100^{\circ} \mathrm{C}$ was held for 15 min then increased at $10^{\circ} \mathrm{C} / \mathrm{min}$ to $150^{\circ} \mathrm{C}$, held for $5 \mathrm{~min}$, then increased at $1^{\circ} \mathrm{C} / \mathrm{min}$ to $158^{\circ} \mathrm{C}$ and held for $30 \mathrm{~min}$, and then increased at $1^{\circ} \mathrm{C} / \mathrm{min}$ to $200^{\circ} \mathrm{C}$ and held for $40 \mathrm{~min}$. Nonadecanoic acid methyl ester was used as internal standard and peak identification was based on cochromatography with known standards of fatty acid methyl esters (Sigma, St. Louis, MO) and, when no commercial standards were available, by using published chromatograms obtained with similar analytic conditions (CruzHernandez et al., 2004; Alves et al., 2006).

Jugular plasma was analyzed for glucose, urea, and total proteins (automated chemistry analyzer AUG40, Olympus, Melville, NY) by, respectively, enzymatic (glucose-oxidase and urease) and colorimetric (biuret) methods described by Bauer (1982). Plasma insulin was determined by chemiluminescent immunoassay (Immulite 1000, DPC, Los Angeles, CA).

\section{Statistical Analysis}

Data from the last week of each experimental period were analyzed as replicated incomplete $4 \times 4$ Latin squares using the MIXED procedure of SAS (SAS Institute, Inc., Cary, NC). The model included the fixed effects of square, period, dietary CP, and starch concentrations, and the interaction dietary $\mathrm{CP} \times$ dietary starch concentrations, the random effect of cow within square, and the random residual error.

Fatty acid profiles of milk samples were analyzed by repeated measures with the MIXED procedure (SAS Institute, Inc.) with milking time as the repeated measurement. The first-order autoregressive covariance structure was used according to finite sample corrected Akaike's information criterion and Schwarz's Bayesian information criterion (Wang and Goonewardene, 2004). The model included the fixed effects square, period, 
Table 2. Chemical analysis and fatty acid composition of the individual ingredients and dietary treatments ${ }^{1}$

\begin{tabular}{|c|c|c|c|c|c|c|c|c|c|c|}
\hline \multirow[b]{2}{*}{ Item } & \multicolumn{2}{|c|}{ Forage $^{2}$} & \multicolumn{4}{|c|}{ Concentrate mixture } & \multicolumn{4}{|c|}{ Diet } \\
\hline & CS & WS & LPLS & LPHS & HPLS & HPHS & LPLS & LPHS & HPLS & HPHS \\
\hline $\mathrm{DM}, \%$ & 32.9 & 87.1 & 90.9 & 90.3 & 91.5 & 90.4 & 64.6 & 64.3 & 64.9 & 64.4 \\
\hline $\mathrm{pH}$ & 3.4 & $\mathrm{ND}^{3}$ & ND & ND & ND & ND & ND & ND & ND & ND \\
\hline Ash & 3.0 & 5.9 & 10.1 & 9.2 & 9.7 & 9.2 & 6.7 & 6.2 & 6.5 & 6.2 \\
\hline $\mathrm{CP}$ & 6.8 & 2.9 & 19.9 & 20.0 & 23.9 & 24.0 & 13.2 & 13.2 & 15.2 & 15.2 \\
\hline NDF & 46.4 & 80.9 & 27.9 & 25.8 & 28.1 & 25.5 & 38.9 & 37.8 & 39.0 & 37.7 \\
\hline $\mathrm{ADF}$ & 28.1 & 52.0 & 16.4 & 13.5 & 16.6 & 13.7 & 23.4 & 22.0 & 23.5 & 22.1 \\
\hline Acid detergent lignin & 3.6 & 6.2 & 4.8 & 3.8 & 4.1 & 4.0 & 4.3 & 3.8 & 4.0 & 3.9 \\
\hline Sugars & 1.1 & 1.2 & 14.5 & 7.8 & 13.3 & 6.9 & 7.8 & 4.5 & 7.2 & 4.0 \\
\hline Starch & 29.1 & ND & 4.6 & 20.7 & 4.8 & 21.7 & 15.4 & 23.4 & 15.5 & 23.9 \\
\hline $\mathrm{Ca}$ & 0.2 & 0.3 & 1.5 & 1.3 & 1.2 & 1.0 & 0.9 & 0.8 & 0.7 & 0.6 \\
\hline $\mathrm{P}$ & 0.2 & 0.1 & 0.6 & 0.6 & 0.6 & 0.6 & 0.4 & 0.4 & 0.4 & 0.4 \\
\hline \multicolumn{11}{|l|}{ Fatty acids } \\
\hline Total & 2.6 & 0.5 & 3.5 & 3.4 & 4.1 & 4.1 & 3.0 & 2.9 & 3.2 & 3.3 \\
\hline $\mathrm{C}_{12: 0}$ & 0.09 & 0.01 & 0.01 & 0.02 & 0.03 & 0.02 & 0.04 & 0.05 & 0.05 & 0.05 \\
\hline $\mathrm{C}_{14: 0}$ & 0.01 & 0.03 & 0.03 & 0.02 & 0.03 & 0.02 & 0.02 & 0.01 & 0.02 & 0.01 \\
\hline $\mathrm{C}_{16: 0}$ & 0.43 & 0.17 & 1.42 & 0.92 & 1.56 & 1.00 & 0.91 & 0.66 & 0.98 & 0.70 \\
\hline $\mathrm{C}_{18: 0}$ & 0.08 & 0.06 & 0.47 & 0.28 & 0.52 & 0.35 & 0.27 & 0.18 & 0.30 & 0.21 \\
\hline $\mathrm{C}_{18: 1}$ cis -9 & 0.46 & 0.05 & 0.48 & 0.74 & 0.54 & 0.84 & 0.45 & 0.58 & 0.48 & 0.63 \\
\hline$C_{18: 2} n-6$ & 1.19 & 0.10 & 0.85 & 1.16 & 1.11 & 1.69 & 0.96 & 1.12 & 1.10 & 1.38 \\
\hline $\mathrm{C}_{20: 0}$ & 0.13 & 0.01 & 0.01 & 0.01 & 0.02 & 0.02 & 0.07 & 0.07 & 0.07 & 0.07 \\
\hline $\mathrm{C}_{18: 3} \mathrm{n}-3$ & 0.17 & 0.02 & 0.07 & 0.05 & 0.09 & 0.07 & 0.11 & 0.11 & 0.12 & 0.11 \\
\hline Unidentified & 0.10 & 0.02 & 0.19 & 0.24 & 0.16 & 0.14 & 0.14 & 0.16 & 0.13 & 0.12 \\
\hline $\mathrm{NE}_{\mathrm{L}},{ }^{4} \mathrm{Mcal} / \mathrm{kg}$ of $\mathrm{DM}$ & - & - & - & - & - & - & 1.5 & 1.5 & 1.5 & 1.5 \\
\hline
\end{tabular}

${ }^{1}$ Diets are named according to the level [low $(\mathrm{L})$ or high $\left.(\mathrm{H})\right]$ of dietary $\mathrm{CP}(\mathrm{P})$ and starch $(\mathrm{S})$ concentrations (\% of DM), respectively: LPLS $=14 \% \mathrm{CP}$ and $15 \%$ starch; LPHS $=14 \% \mathrm{CP}$ and $25 \%$ starch; HPLS $=16 \%$ $\mathrm{CP}$ and $15 \%$ starch; HPHS $=16 \% \mathrm{CP}$ and $25 \%$ starch.

${ }^{2} \mathrm{CS}=$ corn silage; $\mathrm{WS}=$ wheat straw.

${ }^{3} \mathrm{ND}=$ not determined.

${ }^{4}$ Estimated from the NRC (2001).

dietary $\mathrm{CP}$, and starch concentrations, the interaction dietary $\mathrm{CP} \times$ dietary starch concentrations and milking time, and the random effect of cow within square and the random residual error. Mean milk fatty acid profiles, calculated per cow and dietary treatment, were further subjected to principal component factor analysis using the FACTOR procedure of SAS (SAS Institute, Inc.).

\section{RESULTS AND DISCUSSION}

Mean maximum and minimum daily barn temperatures were, respectively, $12.9^{\circ} \mathrm{C}(\mathrm{SD}=2.97)$ and $4.7^{\circ} \mathrm{C}$ $(\mathrm{SD}=2.64)$.

The chemical and fatty acid compositions of the individual ingredients and dietary treatments are given in Table 2. The corn silage contained $46.4 \%$ NDF (DM basis) and $29.1 \%$ starch (DM basis). The chemical composition of concentrate mixtures agreed closely with the ingredient composition. The formulation objectives were not achieved totally, with the dietary CP concentrations being slightly lower than the target 14 and 16\% (DM basis), and the dietary starch concentrations slightly higher than $15 \%$ and lower than $25 \%$ (DM ba- sis). Fatty acid composition of diets reflected both the inclusion of hydrogenated fat and corn grain, respectively, in the low- and high-starch concentrate mixtures.

\section{Feed Intake, Milk Production, and Milk Composition}

Effects on feed intake, milk production, and milk composition are presented in Table 3. There were reductions in feed intake, milk production, and milk protein concentration with the LPLS diet. The reduced intake may have resulted from the highly rumen-fermentable carbohydrate of citrus pulp leading to a shortage of RDP (Rodriguez et al., 1997; Cabrita et al., 2003b). This suggestion is supported by the lower plasma urea concentration for this diet (Table 4). Increasing the CP concentration of the low starch (high citrus pulp) diet (HPLS) avoided the reductions in feed intake and milk production, probably by satisfying the microbial requirement for RDP. The suggestion that citrus pulp exacerbated the effect of low dietary protein is supported by the dietary $\mathrm{CP} \times$ starch interaction for DMI $(P=0.067)$, milk yield, milk protein, and lactose $(P=$ 
Table 3. Least squares means for DMI, milk production, milk composition, and BW from the different dietary treatments

\begin{tabular}{|c|c|c|c|c|c|c|c|c|}
\hline \multirow[b]{2}{*}{ Item } & \multicolumn{4}{|c|}{ Treatment $^{1}$} & \multirow[b]{2}{*}{ SEM } & \multicolumn{3}{|c|}{ Effects } \\
\hline & LPLS & LPHS & HPLS & HPHS & & $\mathrm{CP}$ & Starch & $\mathrm{CP} \times \mathrm{starch}$ \\
\hline $\mathrm{n}$ & 9 & 9 & 9 & 9 & - & - & - & - \\
\hline DMI, kg/d & 22.3 & 24.7 & 24.1 & 24.7 & 0.62 & 0.058 & 0.005 & 0.067 \\
\hline \multicolumn{9}{|l|}{ Milk } \\
\hline Yield, kg/d & 31.9 & 35.2 & 35.1 & 34.9 & 1.30 & 0.026 & 0.026 & 0.013 \\
\hline $\mathrm{ECM},{ }^{2} \mathrm{~kg} / \mathrm{d}$ & 34.9 & 37.6 & 38.1 & 36.9 & 1.29 & 0.086 & 0.313 & 0.013 \\
\hline Fat, \% & 4.58 & 4.44 & 4.56 & 4.39 & 0.154 & 0.774 & 0.231 & 0.901 \\
\hline Protein, \% & 2.98 & 3.09 & 3.08 & 3.07 & 0.049 & 0.109 & 0.037 & 0.014 \\
\hline Lactose, \% & 4.81 & 4.89 & 4.86 & 4.82 & 0.035 & 0.828 & 0.514 & 0.058 \\
\hline Fat, kg/d & 1.22 & 1.23 & 1.29 & 1.19 & 0.067 & 0.769 & 0.511 & 0.395 \\
\hline Protein, kg/d & 1.18 & 1.40 & 1.43 & 1.38 & 0.079 & 0.112 & 0.237 & 0.084 \\
\hline Lactose, kg/d & 1.53 & 1.72 & 1.71 & 1.69 & 0.066 & 0.035 & 0.013 & 0.003 \\
\hline Yield/DMI & 1.43 & 1.42 & 1.45 & 1.41 & 0.035 & 0.762 & 0.267 & 0.345 \\
\hline ECM/DMI & 1.56 & 1.52 & 1.58 & 1.49 & 0.037 & 0.873 & 0.044 & 0.381 \\
\hline Milk fat/DMI & 0.055 & 0.050 & 0.053 & 0.049 & 0.002 & 0.602 & 0.045 & 0.905 \\
\hline Milk protein/CPI ${ }^{3}$ & 0.39 & 0.42 & 0.38 & 0.35 & 0.021 & 0.059 & 0.896 & 0.184 \\
\hline BW, kg & 631 & 638 & 641 & 633 & 15.2 & 0.503 & 0.858 & 0.034 \\
\hline
\end{tabular}

${ }^{1}$ Diets are named according to the level [low $(\mathrm{L})$ or high $\left.(\mathrm{H})\right]$ of dietary $\mathrm{CP}(\mathrm{P})$ and starch $(\mathrm{S})$ concentrations $(\%$ of DM), respectively: LPLS $=14 \% \mathrm{CP}$ and $15 \%$ starch; LPHS $=14 \% \mathrm{CP}$ and $25 \%$ starch; HPLS $=16 \%$ $\mathrm{CP}$ and $15 \%$ starch; HPHS $=16 \% \mathrm{CP}$ and $25 \%$ starch.

${ }^{2}$ Calculated as $(0.324 \times \mathrm{kg}$ of milk $)+(12.95 \times \mathrm{kg}$ of milk fat $)+(7.20 \times \mathrm{kg}$ of milk protein $)$.

${ }^{3}$ Milk protein/CP intake.

$0.058)$ concentrations, and milk protein $(P=0.084)$ and lactose yields (Table 3).

Plasma concentrations of glucose and insulin were lower for the low-starch diets (Table 4), reflecting the low supply of glucogenic nutrients. This is particularly important for ruminants that rely heavily on liver synthesis of glucose to meet their metabolic requirements. The principal substrates or carbon sources for glucose synthesis are organic acids from fermentation (mainly propionate and lactate), the carbon skeletons of deaminated AA, and glycerol from the breakdown of triglycerides. When dietary supply of starch is low, the utilization of some AA for gluconeogenesis increases (Lemosquet et al., 2004). Conversely, the increase in glucogenic materials as ruminal propionic acid or postruminal glucose may reduce the utilization of some AA for gluconeogenesis and increase the supply and uptake of gluco- genic AA to the mammary gland, thus increasing milk protein yield (Lemosquet et al., 2004). Besides the sparing effect of glucose on glucogenic AA, Rulquin et al. (2004) demonstrated that the increase of mammary protein synthesis obtained by infusing glucose into the duodenum also could be explained by an increase of mammary arterial blood flow; high AA supply and high glucose entry rate were necessary conditions to direct AA stored in labile protein reserves toward the mammary gland. In the present experiment, there were no differences in productive responses between proteinrich diets and LPHS. This suggests that along with satisfying the RDP requirements of rumen microbes, the sparing effect of AA from the higher supply of glucogenic nutrients allowed this low-protein diet to meet the nutrient requirements of mid lactation dairy cows. Increasing the $\mathrm{CP}$ concentration increased plasma urea

Table 4. Least squares means for plasma concentrations of urea, total proteins, glucose, and insulin from the different dietary treatments

\begin{tabular}{lccccccccc}
\hline & \multicolumn{4}{c}{ Treatment $^{1}$} & & \multicolumn{3}{c}{ Effects } \\
\cline { 2 - 4 } \cline { 8 - 10 } Item & LPLS & LPHS & HPLS & HPHS & SEM & & CP & Starch & CP $\times$ Starch \\
\hline $\mathrm{n}$ & 9 & 9 & 9 & 9 & - & - & - & - \\
Urea, $\mathrm{mg} / \mathrm{dL}$ & 18.4 & 22.4 & 26.1 & 28.4 & 1.67 & $<0.001$ & 0.005 & 0.410 \\
Total proteins, g/dL & 7.53 & 8.25 & 7.66 & 8.46 & 0.307 & & 0.442 & 0.002 & 0.863 \\
Glucose, $\mathrm{mg} / \mathrm{dL}$ & 56.0 & 61.8 & 57.3 & 62.1 & 1.88 & & 0.606 & 0.003 & 0.766 \\
Insulin, $\mu \mathrm{IU} / \mathrm{mL}$ & 2.30 & 3.80 & 1.15 & 3.79 & 1.656 & & 0.439 & 0.011 & 0.447 \\
\hline
\end{tabular}

${ }^{1}$ Diets are named according to the level [low $(\mathrm{L})$ or high $\left.(\mathrm{H})\right]$ of dietary $\mathrm{CP}(\mathrm{P})$ and starch $(\mathrm{S})$ concentrations $(\%$ of DM), respectively: LPLS $=14 \% \mathrm{CP}$ and $15 \%$ starch; LPHS $=14 \% \mathrm{CP}$ and $25 \%$ starch; HPLS $=16 \%$ $\mathrm{CP}$ and $15 \%$ starch; HPHS $=16 \% \mathrm{CP}$ and $25 \%$ starch. 
concentration (Table 4) and tended to decrease the efficiency of conversion of dietary $\mathrm{N}$ into milk $\mathrm{N}$ (Table 3 ).

Milk fat concentration and yield were not affected despite the effect of dietary starch concentration on plasma concentrations of glucose and insulin. However, the milk fat to DMI ratio was lower for high-starch diets. Because the diets used in this experiment were isoenergetic, the results suggest that high-starch diets favor adipose tissue synthesis. This is in agreement with the glucogenic-insulin theory, which proposes that increased insulin release preferentially channels nutrients to adipose tissue (Brockman and Laarveld, 1986).

\section{Milk Fatty Acids}

The dietary effects on milk fatty acid profiles are given in Table 5. Dietary CP concentration decreased $\mathrm{C}_{16: 0}$ and increased iso $\mathrm{C}_{16: 0}, \mathrm{C}_{18: 1}$ trans-11, $\mathrm{C}_{18: 2} \mathrm{n}-6$, $\mathrm{C}_{18: 3} \mathrm{n}-3$, conjugated linoleic acid (CLA) cis-9, trans-11, and $\mathrm{C}_{22: 0}$. Dietary starch concentration had the greatest effect on milk fatty acid profiles. Increasing dietary starch concentration increased $\mathrm{C}_{10: 0}, \mathrm{C}_{11: 0}, \mathrm{C}_{12: 0}, \mathrm{C}_{13: 0}$, $\mathrm{C}_{14: 0}, \mathrm{C} 15: 0_{0}, \mathrm{C}_{16: 1}$ trans-9, $\mathrm{C}_{17: 0}, \mathrm{C}_{18: 1}$ trans-11, $\mathrm{C}_{18: 1}$ trans-16, $\mathrm{C}_{18: 1}$ cis-15, $\mathrm{C}_{18: 2} \mathrm{n}-6$, and CLA cis-9, trans11 and decreased anteiso $\mathrm{C}_{15: 0}, \mathrm{C}_{15: 1}, \mathrm{C}_{16: 0}, \mathrm{C}_{16: 1}$ cis-9, anteiso $\mathrm{C}_{17: 0}, \mathrm{C}_{17: 1}$ cis-8, $\mathrm{C}_{18: 1}$ cis-13, and $\mathrm{C}_{18: 3} \mathrm{n}-3$. The dietary $\mathrm{CP} \times$ starch interaction was significant for $\mathrm{C}_{10: 0}$, $\mathrm{C}_{12: 0}$, anteiso $\mathrm{C}_{17: 0}, \mathrm{C}_{17: 1}$ cis-8, $\mathrm{C}_{18: 1}$ trans -9 , and $\mathrm{C}_{18: 1}$ trans-16.

Principal component factor analysis produces linear combinations of a set of variables that maximize the variation contained within them, displaying most of the original variability in a smaller number of dimensions (factors), and it is often used to reduce the dimensionality of data profiles containing intercorrelated variables. The results of principal component factor analysis on the selected milk fatty acids are presented in Table 6, including factor pattern after varimax rotation (matrix of standardized regression coefficients for each of the original variables on the rotated factors), communalities, and the variance explained by factors retained by the mineigen criterion. In this case, the technique condensed the information within the original variables into 5 factors (independent linear functions of the original variables) that explained $80.4 \%$ of total variation. The meanings of the rotated factors are inferred from the variables significantly loaded on their factors. Factor loadings represent the correlation or linear association between a variable and the latent factor. In general, the larger the absolute size of the factor loading for a variable, the more important the variable is in interpreting the factor. Factor I was associated with fatty acids derived from the activity of $\Delta^{9}$-desaturase $\left(\mathrm{C}_{14: 1}\right.$ cis-9, $\mathrm{C}_{16: 1}$ cis- 9 , and $\mathrm{C}_{17: 1}$ cis-9) in opposition to
$\mathrm{C}_{18: 0}$. Factor II associated $\mathrm{C}_{14: 0}$ with $\mathrm{C}_{18: 1}$ trans-11, $\mathrm{C}_{18: 2}$ n-6, and CLA cis-9, trans- 11 in opposition to $\mathrm{C}_{16: 0}$ and anteiso $\mathrm{C}_{15: 0}$. Factor III associated $\mathrm{C}_{17: 0}$ with $\mathrm{C}_{15: 0}$ in opposition to anteiso $\mathrm{C}_{17: 0}$ and $\mathrm{C}_{18: 3} \mathrm{n}-3$. Factor IV associated iso $\mathrm{C}_{17: 0}$ with $\mathrm{C}_{18: 1}$ trans-10, and to a lesser extent with anteiso $\mathrm{C}_{17: 0}$. Factor $\mathrm{V}$ was strongly linked to variation in $\mathrm{C}_{18: 1}$ cis-9.

Even-Chain Fatty Acids. The medium-chain fatty acids increased with the increase in dietary starch concentration. However, diets differed not only in level and type of rumen fermentable energy, but also in the level of inclusion of hydrogenated fat. These 2 factors must be taken into account when interpreting these data. The replacement of citrus pulp by corn grain would have promoted differences in rumen fermentation and in duodenal glucose supply, making it difficult to distinguish the effects of VFA or glucose supply on milk fatty acid profiles. A lower inhibition of acetyl-CoA carboxylase (Palmquist et al., 1993) and an increased supply of NADPH (Hurtaud et al., 1998) with an increase in glucose supply can contribute to increased de novo synthesis of medium-chain fatty acids with high-starch diets. Additionally, it is well known that dietary longchain fatty acids depress de novo synthesis of fatty acids in the mammary gland (Palmquist and Jenkins, 1980).

Milk $\mathrm{C}_{16: 0}$ concentration was higher with the lowstarch diets, reflecting the higher inclusion of hydrogenated fat in these diets. The higher concentrations of $\mathrm{C}_{18: 2} \mathrm{n}-6$ in high- starch diets reflects the high concentration of this fatty acid in corn. The effects on $\mathrm{C}_{18}$ fatty acids suggest that dietary protein and starch concentrations affected rumen biohydrogenation of polyunsaturated fatty acids. Milk $\mathrm{C}_{18: 1}$ trans-10 concentration has been implicated in milk fat depression (Bradford and Allen, 2004). Interestingly, milk $\mathrm{C}_{18: 1}$ trans-10 concentration for all diets was lower than observed in earlier studies with diets based on corn silage (described by Carvalho et al., 2006) that promoted lower milk fat concentration (A. R. J. Cabrita, R. J. B. Bessa, R. J. Dewhurst, and A. J. M. Fonseca, unpublished data). Concentrations were consistent with the study by Jurjanz et al. (2004) that found lower concentrations of $\mathrm{C}_{18: 1}$ trans-10 with slowly degradable starch (potato) that did not depress milk fat concentration.

High-starch diets increased the intake of $\mathrm{C}_{18: 1}$ cis- 9 and $\mathrm{C}_{18: 2} \mathrm{n}-6$, and high-protein diets increased the intake of $\mathrm{C}_{18: 2} \mathrm{n}-6$ and $\mathrm{C}_{18: 3} \mathrm{n}-3$ (Table 7). Because the level of polyunsaturated fatty acid ingestion is a major factor affecting the pattern of ruminal biohydrogenation of $\mathrm{C}_{18}$ unsaturated fatty acids (Bessa et al., 2000), the effects of concentrations of dietary protein and starch on the pattern of biohydrogenation intermediates are confounded by differences in $\mathrm{C}_{18}$ unsaturated fatty acids intake. Indeed, the concentration of rumenic 
Table 5. Least squares means for milk fatty acid (FA) profiles from the different dietary treatments

\begin{tabular}{|c|c|c|c|c|c|c|c|c|}
\hline \multirow[b]{2}{*}{ Item } & \multicolumn{4}{|c|}{ Treatment ${ }^{1}$} & \multirow[b]{2}{*}{ SEM } & \multicolumn{3}{|c|}{ Effects } \\
\hline & LPLS & LPHS & HPLS & HPHS & & $\mathrm{CP}$ & Starch & $\mathrm{CP} \times$ starch \\
\hline $\mathrm{n}$ & 18 & 18 & 18 & 18 & - & - & - & - \\
\hline \multicolumn{9}{|l|}{$\mathrm{FA}, \mathrm{g} / 100 \mathrm{~g}$ of total FA } \\
\hline $\mathrm{C}_{8: 0}$ & 0.40 & 0.51 & 0.50 & 0.41 & 0.055 & 0.991 & 0.830 & 0.085 \\
\hline $\mathrm{C}_{10: 0}$ & 2.24 & 2.61 & 2.46 & 2.46 & 0.129 & 0.638 & 0.017 & 0.017 \\
\hline $\mathrm{C}_{10: 1}$ & 0.25 & 0.27 & 0.26 & 0.26 & 0.013 & 0.981 & 0.559 & 0.364 \\
\hline $\mathrm{C}_{11: 0}$ & 0.07 & 0.11 & 0.07 & 0.11 & 0.009 & 0.966 & $<0.001$ & 0.735 \\
\hline $\mathrm{C}_{12: 0}$ & 3.21 & 3.76 & 3.47 & 3.67 & 0.185 & 0.129 & $<0.001$ & 0.005 \\
\hline $\mathrm{C}_{13: 0}$ & 0.13 & 0.18 & 0.13 & 0.17 & 0.011 & 0.506 & $<0.001$ & 0.385 \\
\hline Iso $\mathrm{C}_{14: 0}$ & 0.09 & 0.09 & 0.09 & 0.09 & 0.008 & 0.665 & 0.798 & 0.207 \\
\hline $\mathrm{C}_{14: 0}$ & 11.21 & 12.08 & 11.58 & 11.95 & 0.310 & 0.357 & $<0.001$ & 0.073 \\
\hline Iso $\mathrm{C}_{15: 0}$ & 0.23 & 0.23 & 0.23 & 0.24 & 0.008 & 0.561 & 0.746 & 0.165 \\
\hline Anteiso $\mathrm{C}_{15: 0}$ & 0.54 & 0.48 & 0.51 & 0.49 & 0.018 & 0.600 & 0.031 & 0.271 \\
\hline $\mathrm{C}_{14: 1}$ cis-9 & 1.20 & 1.22 & 1.20 & 1.25 & 0.088 & 0.755 & 0.459 & 0.711 \\
\hline $\mathrm{C}_{15: 0}$ & 1.32 & 1.56 & 1.24 & 1.57 & 0.086 & 0.555 & $<0.001$ & 0.532 \\
\hline $\mathrm{C}_{15: 1}$ & 0.03 & 0.02 & 0.03 & 0.02 & 0.002 & 0.041 & 0.006 & 0.619 \\
\hline Iso $\mathrm{C}_{16: 0}$ & 0.19 & 0.19 & 0.20 & 0.22 & 0.016 & 0.030 & 0.250 & 0.245 \\
\hline $\mathrm{C}_{16: 0}$ & 38.91 & 36.55 & 37.54 & 35.66 & 0.775 & 0.011 & $<0.001$ & 0.555 \\
\hline $\mathrm{C}_{16: 1}$ trans -9 & 0.05 & 0.07 & 0.06 & 0.07 & 0.006 & 0.539 & 0.039 & 0.925 \\
\hline Iso $\mathrm{C}_{17: 0}$ & 0.33 & 0.31 & 0.33 & 0.33 & 0.010 & 0.347 & 0.115 & 0.138 \\
\hline $\mathrm{C}_{16: 1}$ cis-7 & 0.24 & 0.21 & 0.22 & 0.22 & 0.009 & 0.657 & 0.129 & 0.135 \\
\hline $\mathrm{C}_{16: 1}$ cis -9 & 1.86 & 1.68 & 1.71 & 1.68 & 0.107 & 0.116 & 0.048 & 0.148 \\
\hline Anteiso $\mathrm{C}_{17: 0}$ & 0.55 & 0.48 & 0.53 & 0.50 & 0.016 & 0.925 & 0.001 & 0.049 \\
\hline $\mathrm{C}_{17: 0}$ & 0.59 & 0.61 & 0.53 & 0.61 & 0.021 & 0.084 & 0.009 & 0.113 \\
\hline $\mathrm{C}_{17: 1}$ cis -8 & 0.09 & 0.07 & 0.08 & 0.08 & 0.003 & 0.736 & 0.003 & 0.006 \\
\hline $\mathrm{C}_{17: 1}$ cis-9 & 0.25 & 0.23 & 0.23 & 0.23 & 0.018 & 0.544 & 0.640 & 0.281 \\
\hline $\mathrm{C}_{18: 0}$ & 8.90 & 9.02 & 9.47 & 9.44 & 0.537 & 0.101 & 0.871 & 0.800 \\
\hline $\mathrm{C}_{18: 1}$ trans $-6-8$ & 0.26 & 0.26 & 0.30 & 0.28 & 0.016 & 0.111 & 0.340 & 0.686 \\
\hline $\mathrm{C}_{18: 1}$ trans -9 & 0.23 & 0.23 & 0.25 & 0.22 & 0.009 & 0.206 & 0.084 & 0.015 \\
\hline $\mathrm{C}_{18: 1}$ trans -10 & 0.46 & 0.48 & 0.49 & 0.49 & 0.030 & 0.404 & 0.801 & 0.814 \\
\hline $\mathrm{C}_{18: 1}$ trans -11 & 0.84 & 1.12 & 1.03 & 1.17 & 0.096 & 0.022 & $<0.001$ & 0.154 \\
\hline $\mathrm{C}_{18: 1}$ trans -12 & 0.39 & 0.43 & 0.41 & 0.39 & 0.020 & 0.556 & 0.369 & 0.074 \\
\hline $\mathrm{C}_{18: 1}$ cis -9 & 18.29 & 17.70 & 18.16 & 18.46 & 0.497 & 0.334 & 0.707 & 0.163 \\
\hline $\mathrm{C}_{18: 1}$ cis- 11 & 0.79 & 0.77 & 0.67 & 0.79 & 0.045 & 0.216 & 0.152 & 0.054 \\
\hline $\mathrm{C}_{18: 1}$ cis-12 & 0.35 & 0.35 & 0.39 & 0.35 & 0.024 & 0.343 & 0.386 & 0.427 \\
\hline $\mathrm{C}_{18: 1}$ cis -13 & 0.08 & 0.07 & 0.10 & 0.07 & 0.009 & 0.428 & 0.007 & 0.293 \\
\hline $\mathrm{C}_{18: 1}$ trans -16 & 0.26 & 0.31 & 0.28 & 0.29 & 0.008 & 0.970 & $<0.001$ & 0.019 \\
\hline $\mathrm{C}_{18: 1}$ cis -15 & 0.11 & 0.13 & 0.11 & 0.12 & 0.008 & 0.340 & 0.028 & 0.144 \\
\hline $\mathrm{C}_{18: 2} \mathrm{i}^{2}$ & 0.56 & 0.60 & 0.61 & 0.59 & 0.033 & 0.539 & 0.793 & 0.328 \\
\hline $\mathrm{C}_{18: 2} \mathrm{n}-6$ & 1.90 & 2.07 & 1.99 & 2.22 & 0.104 & 0.044 & 0.003 & 0.587 \\
\hline $\mathrm{C}_{20: 0}$ & 0.12 & 0.11 & 0.13 & 0.12 & 0.009 & 0.199 & 0.503 & 0.757 \\
\hline $\mathrm{C}_{18: 3} \mathrm{n}-6$ & 0.04 & 0.04 & 0.03 & 0.04 & 0.004 & 0.377 & 0.479 & 0.769 \\
\hline $\mathrm{C}_{18: 3} \mathrm{n}-3$ & 0.29 & 0.26 & 0.30 & 0.28 & 0.009 & 0.013 & 0.003 & 0.285 \\
\hline $\mathrm{C}_{20: 1} \mathrm{n}-9$ & 0.05 & 0.05 & 0.04 & 0.05 & 0.004 & 0.521 & 0.478 & 0.912 \\
\hline $\mathrm{CLA}^{3}$ cis -9, trans -11 & 0.41 & 0.55 & 0.51 & 0.59 & 0.041 & 0.021 & $<0.001$ & 0.295 \\
\hline $\mathrm{C}_{22: 0}$ & 0.03 & 0.02 & 0.04 & 0.03 & 0.003 & 0.041 & 0.055 & 0.290 \\
\hline $\mathrm{C}_{20: 3} \mathrm{n}-6$ & 0.11 & 0.13 & 0.14 & 0.13 & 0.014 & 0.431 & 0.941 & 0.322 \\
\hline Unidentified & 1.53 & 1.70 & 1.43 & 1.57 & 0.092 & 0.116 & 0.035 & 0.903 \\
\hline
\end{tabular}

${ }^{1}$ Diets are named according to the level [low $(\mathrm{L})$ or high $\left.(\mathrm{H})\right]$ of dietary $\mathrm{CP}(\mathrm{P})$ and starch $(\mathrm{S})$ concentrations (\% DM), respectively: LPLS $=14 \% \mathrm{CP}$ and $15 \%$ starch; LPHS $=14 \% \mathrm{CP}$ and $25 \%$ starch; HPLS $=16 \% \mathrm{CP}$ and $15 \%$ starch; HPHS $=16 \% \mathrm{CP}$ and $25 \%$ starch.

${ }^{2}$ Nonconjugated isomers of $\mathrm{C}_{18: 2}$.

${ }^{3} \mathrm{CLA}=$ conjugated linoleic acid.

acid (CLA cis-9, trans-11) and its precursor $\left(\mathrm{C}_{18: 1}\right.$ trans11) in milk fat increased with both dietary protein and starch concentrations. Results from principal component factor analysis (Table 6) also add support to these confounding effects. The lack of association of $\mathrm{C}_{18: 1}$ cis9 (with high load in factor $\mathrm{V}$ ) with the other fatty acids originating from $\Delta^{9}$-desaturase activity $\left(\mathrm{C}_{14: 1}\right.$ cis-9, $\mathrm{C}_{16: 1}$ cis-9, $\mathrm{C}_{17: 1}$ cis-9; factor I) suggests that intake of $\mathrm{C}_{18: 1}$ cis-9 had an important effect on its secretion in milk. Additionally, factor II associated CLA cis-9, trans-11 with its precursor and also with $\mathrm{C}_{18: 2} \mathrm{n}-6$ in opposition to $\mathrm{C}_{16: 0}$, reflecting the high concentration of polyunsaturated fatty acids in high-starch diets as well as the inclusion of hydrogenated fat in low-starch diets.

The apparent transfer of dietary $\mathrm{C}_{18: 2} \mathrm{n}-6$ and $\mathrm{C}_{18: 3}$ $\mathrm{n}-3$ into milk is presented in Table 7 . The range of 
Table 6. Factor pattern, after varimax rotation, communalities, and variance explained by the 5 factors ${ }^{1}$ retained by the mineigen criterion, through the principal component factor analysis on the selected milk fatty acids

\begin{tabular}{|c|c|c|c|c|c|c|}
\hline \multirow[b]{2}{*}{ Variable } & \multicolumn{5}{|c|}{ Factor } & \multirow[b]{2}{*}{ Communalities } \\
\hline & $\mathrm{I}$ & II & III & IV & $\mathrm{V}$ & \\
\hline Iso $\mathrm{C}_{14: 0}$ & -0.581 & -0.002 & 0.314 & -0.279 & -0.572 & 0.842 \\
\hline $\mathrm{C}_{14: 0}$ & 0.003 & $0.701^{\mathrm{a}}$ & 0.206 & -0.243 & -0.332 & 0.702 \\
\hline Iso $\mathrm{C}_{15: 0}$ & -0.121 & -0.298 & -0.268 & $-0.558^{\mathrm{a}}$ & -0.410 & 0.655 \\
\hline Anteiso $\mathrm{C}_{15: 0}$ & -0.065 & $-0.804^{\mathrm{a}}$ & 0.305 & -0.090 & -0.053 & 0.754 \\
\hline $\mathrm{C}_{14: 1} c i s-9$ & $0.891^{\mathrm{a}}$ & 0.272 & 0.192 & 0.142 & -0.056 & 0.929 \\
\hline $\mathrm{C}_{15: 0}$ & 0.513 & 0.064 & $-0.730^{\mathrm{a}}$ & -0.080 & 0.043 & 0.809 \\
\hline Iso $\mathrm{C}_{16: 0}$ & -0.497 & 0.102 & 0.421 & -0.108 & -0.492 & 0.688 \\
\hline $\mathrm{C}_{16: 0}$ & 0.294 & $-0.707^{\mathrm{a}}$ & -0.384 & 0.084 & -0.327 & 0.847 \\
\hline Iso $\mathrm{C}_{17: 0}$ & 0.073 & -0.374 & 0.012 & $0.761^{\mathrm{a}}$ & 0.092 & 0.733 \\
\hline $\mathrm{C}_{16: 1}$ cis -9 & $0.854^{\mathrm{a}}$ & -0.287 & -0.049 & 0.129 & 0.172 & 0.860 \\
\hline Anteiso $\mathrm{C}_{17: 0}$ & 0.293 & -0.380 & $0.699^{\mathrm{a}}$ & 0.385 & 0.148 & 0.889 \\
\hline $\mathrm{C}_{17: 0}$ & 0.161 & -0.271 & $-0.743^{\mathrm{a}}$ & 0.149 & 0.121 & 0.689 \\
\hline $\mathrm{C}_{17: 1}$ cis-9 & $0.810^{\mathrm{a}}$ & -0.139 & -0.121 & -0.074 & 0.419 & 0.871 \\
\hline $\mathrm{C}_{18: 0}$ & $-0.917^{\mathrm{a}}$ & -0.088 & 0.070 & -0.306 & 0.018 & 0.947 \\
\hline $\mathrm{C}_{18: 1}$ trans -10 & 0.246 & 0.114 & 0.057 & $0.867^{\mathrm{a}}$ & -0.105 & 0.839 \\
\hline $\mathrm{C}_{18: 1}$ trans -11 & -0.367 & $0.738^{\mathrm{a}}$ & 0.142 & -0.268 & -0.129 & 0.788 \\
\hline $\mathrm{C}_{18: 1} c i s-9$ & 0.131 & -0.152 & 0.207 & -0.030 & $0.863^{\mathrm{a}}$ & 0.828 \\
\hline$C_{18: 2} n-6$ & 0.017 & $0.718^{\mathrm{a}}$ & 0.539 & 0.217 & -0.042 & 0.855 \\
\hline $\mathrm{C}_{18: 3} \mathrm{n}-3$ & 0.121 & 0.265 & $0.775^{\mathrm{a}}$ & 0.150 & 0.223 & 0.758 \\
\hline CLA cis-9, trans-11 & 0.207 & $0.857^{\mathrm{a}}$ & 0.095 & 0.078 & -0.096 & 0.802 \\
\hline Percentage of variance & 29.75 & 21.80 & 14.55 & 7.77 & 6.56 & - \\
\hline
\end{tabular}

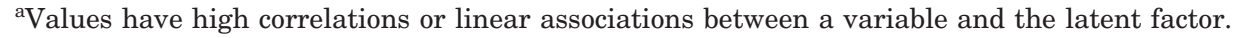

${ }^{1}$ Independent linear functions of the original variables obtained through the principal component factor analysis.

values observed is similar to that reported by others (Lourenço et al., 2005; Shingfield et al., 2005). Dietary starch decreased the apparent transfer of dietary $\mathrm{C}_{18: 2}$ n-6, $\mathrm{C}_{18: 3} \mathrm{n}-3(P=0.09)$, and total $\mathrm{C}_{18}$ fatty acids into milk. The decrease of apparent transfer of both $\mathrm{C}_{18: 2}$ $\mathrm{n}-6$ and $\mathrm{C}_{18: 3} \mathrm{n}-3$ contradicts several reports relating

Table 7. Least squares means for intake, milk output, and apparent transfer of ingested $\mathrm{C}_{18}$ fatty acids into milk

\begin{tabular}{|c|c|c|c|c|c|c|c|c|}
\hline \multirow[b]{2}{*}{ Item } & \multicolumn{4}{|c|}{ Treatment $^{1}$} & \multirow[b]{2}{*}{ SEM } & \multicolumn{3}{|c|}{ Effects } \\
\hline & LPLS & LPHS & HPLS & HPHS & & $\mathrm{CP}$ & Starch & $\mathrm{CP} \times$ starch \\
\hline $\mathrm{n}$ & 9 & 9 & 9 & 9 & - & - & - & - \\
\hline \multicolumn{9}{|l|}{ Intake $(\mathrm{g} / \mathrm{d})$} \\
\hline $\mathrm{C}_{18: 3} \mathrm{n}-3$ & 25.3 & 25.6 & 29.2 & 28.2 & 0.8 & $<0.001$ & 0.632 & 0.311 \\
\hline $\mathrm{C}_{18 \cdot 2} \mathrm{n}-6$ & 225 & 276 & 264 & 344 & 8.0 & $<0.001$ & $<0.001$ & 0.043 \\
\hline Total $\mathrm{C}_{18}$ & 415 & 488 & 481 & 580 & 13.9 & $<0.001$ & $<0.001$ & 0.249 \\
\hline \multicolumn{9}{|l|}{ Milk output $(\mathrm{g} / \mathrm{d})^{2}$} \\
\hline $\mathrm{C}_{18: 3} \mathrm{n}-3$ & 3.34 & 3.02 & 3.64 & 3.20 & 0.213 & 0.227 & 0.057 & 0.740 \\
\hline $\mathrm{C}_{18: 2} \mathrm{n}-6$ & 22.1 & 24.5 & 24.5 & 25.1 & 1.89 & 0.345 & 0.334 & 0.578 \\
\hline $\mathrm{C}_{18 \cdot 2}$ cis -9, trans -11 & 4.8 & 6.6 & 6.1 & 6.8 & 0.63 & 0.111 & 0.016 & 0.232 \\
\hline $\mathrm{C}_{18: 1}$ trans -11 & 9.6 & 13.4 & 12.8 & 12.9 & 1.55 & 0.220 & 0.087 & 0.108 \\
\hline $\mathrm{C}_{18: 1}$ trans -10 & 5.4 & 5.7 & 5.8 & 5.8 & 0.46 & 0.494 & 0.649 & 0.534 \\
\hline Total $\mathrm{C}_{18}$ & 394 & 402 & 433 & 403 & 27.6 & 0.427 & 0.659 & 0.441 \\
\hline \multicolumn{9}{|l|}{ Apparent transfer ${ }^{3}(\%)$} \\
\hline $\mathrm{C}_{18: 3} \mathrm{n}-3$ & 13.3 & 11.8 & 12.4 & 11.4 & 0.75 & 0.347 & 0.088 & 0.697 \\
\hline $\mathrm{C}_{18: 2} \mathrm{n}-6$ & 10.0 & 8.8 & 9.1 & 7.3 & 0.68 & 0.060 & 0.021 & 0.570 \\
\hline $\mathrm{C}_{18: 1} c i s-9$ & 208 & 144 & 194 & 134 & 12.9 & 0.311 & $<0.001$ & 0.828 \\
\hline $\mathrm{C}_{18: 0}$ & 164 & 245 & 159 & 196 & 13.3 & 0.020 & $<0.001$ & 0.048 \\
\hline Total $\mathrm{C}_{18}$ & 95.4 & 82.0 & 89.8 & 69.6 & 5.58 & 0.109 & 0.005 & 0.535 \\
\hline
\end{tabular}

${ }^{1}$ Diets are named according to the level [low $(\mathrm{L})$ or high $\left.(\mathrm{H})\right]$ of dietary $\mathrm{CP}(\mathrm{P})$ and starch $(\mathrm{S})$ concentrations (\% of DM), respectively: LPLS $=14 \% \mathrm{CP}$ and $15 \%$ starch; LPHS $=14 \% \mathrm{CP}$ and $25 \%$ starch; HPLS $=16 \%$ $\mathrm{CP}$ and $15 \%$ starch; HPHS $=16 \% \mathrm{CP}$ and $25 \%$ starch.

${ }^{2}$ Calculated as: milk fat $(\mathrm{kg} / \mathrm{d}) \times 0.945 \times($ fatty acid percentage $/ 100)$.

${ }^{3}$ Calculated as: 1 - (intake - output)/intake $\times 100$. 


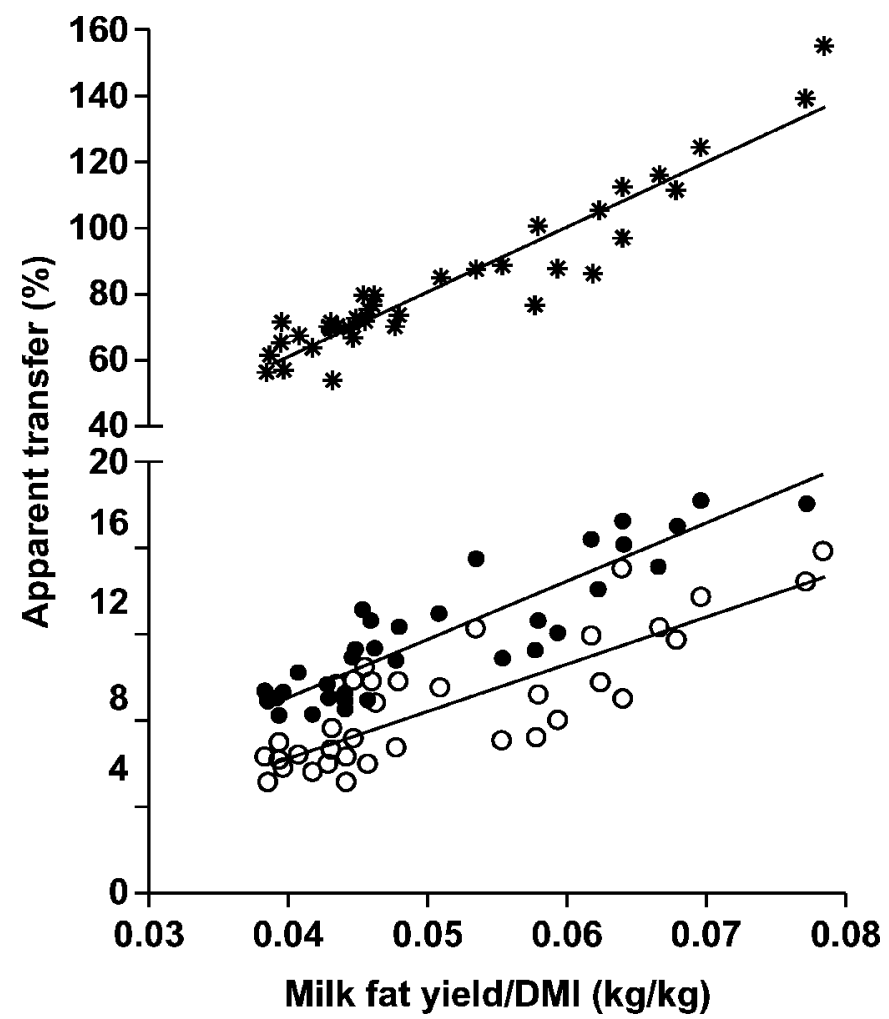

Figure 1. Relationship between milk fat yield per DMI and apparent transfer of ingested $\mathrm{C}_{18: 2} \mathrm{n}-6(\mathrm{O}), \mathrm{C}_{18: 3} \mathrm{n}-3(\bullet)$, and total $\mathrm{C}_{18}$ fatty acids (*) into milk. $\mathrm{C}_{18: 2} \mathrm{n}-6: \mathrm{Y}=-2.4 \pm 1.32+0.22 \pm 0.025 \mathrm{X}, \mathrm{r}^{2}=$ $0.69, \mathrm{RSD}=1.68, P<0.0001 ; \mathrm{C}_{18: 3} \mathrm{n}-3: \mathrm{Y}=-1.7 \pm 1.06+0.27 \pm$ $0.020 \mathrm{X}, \mathrm{r}^{2}=0.84, \mathrm{RSD}=1.35, P<0.0001$; total $\mathrm{C}_{18}$ fatty acids: $\mathrm{Y}=$ $-16.9 \pm 6.06+1.96 \pm 0.115 \mathrm{X}, \mathrm{r}^{2}=0.89, \mathrm{RSD}=7.72, P<0.0001$.

increased dietary starch with inhibition of rumen lipolysis and biohydrogenation of $\mathrm{C}_{18}$ unsaturated fatty acids (Doreau and Ferlay, 1994). However, diet effects on biohydrogenation and duodenal flow of $\mathrm{C}_{18}$ unsaturated fatty acids are controversial. Data reviewed by Chilliard et al. (2000) show a great variation in the transfer efficiency into milk of linoleic acid (10 to 90\%) or linolenic acid (35 to 70\%) infused into the duodenum. The negative effect of high-concentrate diets on rumen biohydrogenation of unsaturated fatty acids in some studies has been related to a reduction in rumen $\mathrm{pH}$ (Kucuk et al., 2001) or to dietary starch concentration (Loor et al., 2004), although these effects have not been consistent.

The simultaneous decrease in apparent transfer of total dietary $\mathrm{C}_{18}$ fatty acids suggest that factors other than biohydrogenation might be involved in affecting the transfer of dietary $\mathrm{C}_{18: 2}$ and $\mathrm{C}_{18: 3}$ into milk. In Figure 1 , a direct relationship between apparent transfer of dietary $\mathrm{C}_{18}$ fatty acid and the milk fat yield per DMI is shown. Considering that diets are isoenergetic, this relation can be considered an indicator of nutrient par- titioning between the mammary gland and nonmammary tissues; Figure 1 and Table 7 show that an increase in dietary starch channels fatty acids to adipose tissue, reducing the apparent transfer of dietary polyunsaturated fatty acids to milk. This, along with the observed effects of dietary starch on plasma insulin, agrees with the glucogenic-insulin theory, because this theory proposes that milk fat depression is caused by increased concentrations of circulating insulin stimulated by a high supply of propionate and glucose (Brockman and Laarveld, 1986). Because of the preferential effects of insulin in stimulating the use of acetate and preformed fatty acids by adipose tissue, the mammary gland has a shortage of these milk fat precursors.

Odd-Chain Fatty Acids. Recently, some studies have related the presence of odd- and branched-chain fatty acids in milk (major components of the fatty acids of rumen microorganisms; O'Kelly and Spiers, 1991) with differences in feeding strategies (Cabrita et al., 2003a). Linear odd-chain fatty acids $\left(\mathrm{C}_{15: 0}\right.$ and $\left.\mathrm{C}_{17: 0}\right)$ accounted for the majority of milk odd- and branchedchain fatty acids, followed by anteiso fatty acids. The high proportion of $\mathrm{C}_{15: 0}$ in the total odd- and branchedchain fatty acids in this study is consistent with observations with pure rumen bacteria (Minato et al., 1988).

Dietary starch concentration increased $\mathrm{C}_{15: 0}$ and $\mathrm{C}_{17: 0}$ and decreased anteiso $\mathrm{C}_{15: 0}, \mathrm{C}_{15: 1}$, anteiso $\mathrm{C}_{17: 0}$, and $\mathrm{C}_{17: 1}$ cis-8. Dewhurst et al. (accepted) found yields of $\mathrm{C}_{15: 0}$ and $\mathrm{C}_{17: 0}$ in milk that exceeded duodenal flows, suggesting that these fatty acids can be synthesized de novo. Also, comparisons of the ratios of $\mathrm{C}_{15: 0}$ to anteiso $\mathrm{C}_{15: 0}$ fatty acids in jugular plasma and milk fat in the study of Loor et al. (2005) suggested a relative increase of $\mathrm{C}_{15: 0}$ in milk, but not of $\mathrm{C}_{17: 0}$. Earlier studies have shown that the linear odd-chain fatty acids $\left(\mathrm{C}_{15: 0}\right.$ and $\mathrm{C}_{17: 0}$ ) can be synthesized de novo from propionate (Scaife et al., 1978; Massart-Leën et al., 1983), with the evidence being stronger for $\mathrm{C}_{15: 0}$ than $\mathrm{C}_{17: 0}$ (Rigout et al., 2003), suggesting a limited ability to elongate $C_{15: 0}$ to $\mathrm{C}_{17: 0}$. Furthermore, $\mathrm{C}_{17: 0}$ appears to be desaturated to $\mathrm{C}_{17: 1}$ cis-9 by $\Delta^{9}$-desaturase (Fievez et al., 2003). The increase in milk $\mathrm{C}_{15: 0}$ and $\mathrm{C}_{17: 0}$ occurred despite the general effect of starch in decreasing the extent of transfer of fatty acids from diet to milk. This suggests a real increase in levels of this fatty acid between the diet and milk. This effect could reflect both an increase in starchfermenting bacteria that contain relatively high concentrations of $\mathrm{C}_{15: 0}$ and $\mathrm{C}_{17: 0}$ (Minato et al., 1988) and a higher supply of propionate as a precursor for $\mathrm{C}_{15: 0}$ and $\mathrm{C}_{17: 0}$. Indeed, principal component factor analysis associated $\mathrm{C}_{15: 0}$ and $\mathrm{C}_{17: 0}$ in factor III in opposition to anteiso $\mathrm{C}_{17: 0}$ and $\mathrm{C}_{18: 3} \mathrm{n}-3$, the other odd-chain fatty acids having high loads in other factors. This suggestion could limit the value of these fatty acids as markers of 
rumen microbial population, as previously suggested (Cabrita et al., 2003a). The strong association of $\mathrm{C}_{17: 1}$ $c i s-9$ with $\mathrm{C}_{14: 1}$ cis-9 and $\mathrm{C}_{16: 1}$ cis-9 in factor I supports the synthesis of this fatty acid by $\Delta^{9}$-desaturase in the mammary gland.

The observed increase in odd branched-chain fatty acids with low-starch diets suggests greater rumen fermentation with these diets, as mentioned above. Additionally, the high concentrations of anteiso $\mathrm{C}_{15: 0}$ observed with citrus pulp diets agrees with the high concentrations of this fatty acid in fibrolytic bacteria (Minato et al., 1988), and it is consistent with the results from Cabrita et al. (2003a), who found a positive correlation between dietary sugar concentration and anteiso $\mathrm{C}_{15: 0}$. Its association in factor II with $\mathrm{C}_{16: 0}$ (related to the inclusion of hydrogenated fat in low-starch diets) in opposition to $\mathrm{C}_{18: 2} \mathrm{n}-6, \mathrm{C}_{18: 1}$ trans-11, and CLA cis9, trans-11 (related to high dietary starch concentration) also shows a diet effect on this fatty acid.

Wongtangtintharn et al. (2004) suggested that branched-chain fatty acids lower fatty acid synthesis in breast cancer cells. In the present study, the proportions of the de novo synthesized fatty acids were affected in the opposite direction to branched-chain fatty acids, but similarly to linear odd-chain fatty acids. This gives an indication that the linear odd-chain fatty acids in milk have a dual origin and would be consistent with a direct inhibitory effect of these fatty acids on fatty acid synthesis in the mammary gland.

\section{CONCLUSIONS}

This study shows that to reduce the protein concentration of diets for mid lactation dairy cows, the requirements of rumen microbes for RDP and of the cow for glucogenic nutrients must be satisfied, respectively, to not limit feed intake and to direct AA use toward milk protein synthesis. Milk fatty acid profiles were affected by starch (corn) and protein supply, with starch having the most important effect. Additionally, increasing dietary starch concentration decreased the apparent transfer of dietary polyunsaturated fatty acids to milk, suggesting an increased channeling of fatty acids to adipose tissue. The results further suggest that $\mathrm{C}_{15: 0}$ and $\mathrm{C}_{17: 0}$ are synthesized de novo in the animal tissues, because these fatty acids were increased by dietary starch concentration despite its general effect of reducing the transfer of $\mathrm{C}_{18}$ fatty acids from the diet to milk.

\section{ACKNOWLEDGMENTS}

This work was partially financed by the Instituto Nacional de Investigação Agrária e Pescas (INIAP, Portugal), Projecto 342, Medida 8, Acção 8.1 do Programa
Agro (European Union), which is gratefully acknowledged. The authors are grateful for the help of the staff of Dairy Unit of Direcção Regional de Agricultura do Entre-Douro e Minho in the care of animals and of the nutrition laboratory of AGROS/University of Porto for the chemical analysis of feed samples.

\section{REFERENCES}

Acker, L. 1967. Analytik der Lebensmittel. Nachweis und Bestimmung der Mono- und Oligosacchariden. Pages 383-401 in Handbuch der Lebensmittel chemie. W. Diemar, ed. Springer-Verlag, Berlin, Germany.

Alves, S. P., C. Marcelino, P. V. Portugal, and R. J. B. Bessa. 2006. Short communication: The nature of heptadecenoic acid in ruminant fats. J. Dairy Sci. 89:170-173.

AOAC. 1990. Official Methods of Analysis. Vol. I. 15th ed. Association of Official Analytical Chemists, Arlington, VA.

Bauer, J. D. 1982. Clinical Laboratory Methods. 9th ed. D. Ladig, ed. C. V. Mosby Co., St. Louis, MO.

Bessa, R. J. B., J. Santos-Silva, J. M. R. Ribeiro, and A. V. Portugal. 2000. Reticulo-rumen biohydrogenation and the enrichment of ruminant edible products with linoleic acid conjugated isomers. Livest. Prod. Sci. 63:201-211.

Bradford, B. J., and M. S. Allen. 2004. Milk fat responses to a change in diet fermentability vary by production level in dairy cattle. J. Dairy Sci. 87:3800-3807.

Brockman, R. P., and B. Laarveld. 1986. Hormonal regulation of metabolism in ruminants: A review. Livest. Prod. Sci. 14:313-334.

Cabrita, A. R. J., A. J. M. Fonseca, R. J. Dewhurst, and E. Gomes. 2003a. Nitrogen supplementation of corn silages. 2. Assessing rumen function using fatty acid profiles of bovine milk. J. Dairy Sci. 86:4020-4032.

Cabrita, A. R. J., A. J. M. Fonseca, R. J. Dewhurst, C. V. P. Sampaio, M. F. S. Miranda, G. N. S. Sousa, I. M. F. Miranda, and E. Gomes. 2003b. Nitrogen supplementation of corn silages. 1. Effects on feed intake and milk production of dairy cows. J. Dairy Sci. 86:4008-4019.

Carlson, L. A. 1985. Extraction of lipids from human whole serum and lipoproteins and from rat liver tissue with methylene chloridemethanol: A comparison with extraction chloroform-methanol. Clin. Chim. Acta 149:89-93.

Carvalho, L. P. F., A. R. J. Cabrita, R. J. Dewhurst, T. E. J. Vicente, Z. M. C. Lopes, and A. J. M. Fonseca. 2006. Evaluation of palm kernel meal and corn distillers grains in corn silage-based diets for lactating dairy cows. J. Dairy Sci. 89:2705-2715.

Chilliard, Y., A. Ferlay, M. R. Mansbridge, and M. Doreau. 2000. Ruminant milk fat plasticity: Nutritional control of saturated, polyunsaturated, trans and conjugated fatty acids. Ann. Zootech. 49:181-205.

Christie, W. W. 2004. Lipid Analysis. 3rd ed. The Oily Press, P. J. Barnes and Associates, Bridgwater, UK.

Cruz-Hernandez, C., Z. Deng, J. Zhou, A. R. Hill, M. P. Yurawecz, P. Delmonte, M. M. Mossoba, M. E. R. Dugan, and J. K. G. Kramer. 2004. Methods for analysis of conjugated linoleic acid and trans18:1 isomers in dairy fats by using a combination of gas chromatography, silver-ion thin-layer chromatography/gas chromatography, and silver-ion liquid chromatography. J. AOAC Int. 87:545-562

Cunningham, K. D., M. J. Cecava, T. R. Johnson, and P. A. Ludden. 1996. Influence of source and amount of dietary protein on milk yield by cows in early lactation. J. Dairy Sci. 79:620-630.

Dewhurst, R. J., J. M. Moorby, B. Vlaeminck, and V. Fievez. 2007. Apparent recovery of duodenal odd- and branched-chain fatty acids in milk in dairy cows. J. Dairy Sci. 90 (accepted).

Doreau, M., and A. Ferlay. 1994. Digestion and utilization of fatty acids by ruminants. Anim. Feed Sci. Technol. 45:379-396.

Fievez, V., B. Vlaeminck, M. S. Dhanoa, and R. J. Dewhurst. 2003. Use of principal component analysis to investigate the origin of 
heptadecenoic and conjugated linoleic acids in milk. J. Dairy Sci. 86:4047-4053.

Folch, J., M. Lees, and G. H. Sloane Stanley. 1957. A simple method for the isolation and purification of total lipids from animal tissues. J. Biol. Chem. 226:497-509.

Griinari, J. M., M. A. McGuire, D. A. Dwyer, D. E. Bauman, and D. L. Palmquist. 1997. Role of insulin in the regulation of milk fat synthesis in dairy cows. J. Dairy Sci. 80:1076-1084.

Huhtanen, P. J., R. Blauwiekel, and I. Saastamoinen. 1998. Effects of intraruminal infusions of propionate and butyrate with two different protein supplements on milk production and blood metabolites in dairy cows receiving grass silage-based diet. J. Sci. Food Agric. 77:213-222.

Hurtaud, C., S. Lemosquet, and H. Rulquin. 2000. Effect of graded duodenal infusions of glucose on yield and composition of milk from dairy cows. 2. Diets based on grass silage. J. Dairy Sci. 83:2952-2962.

Hurtaud, C., H. Rulquin, and R. Verite. 1998. Effects of graded duodenal infusions of glucose on yield and composition of milk from dairy cows. 1. Diets based on corn silage. J. Dairy Sci. 81:3239-3247.

Jurjanz, S., V. Monteils, P. Juaneda, and F. Laurent. 2004. Variations of trans octadecenoic acid in milk fat induced by feeding different starch-based diets to cows. Lipids 39:19-24.

Kebreab, E., J. France, J. A. N. Mills, R. Allison, and J. Dijkstra. 2002. A dynamic model of $\mathrm{N}$ metabolism in the lactating dairy cow and an assessment of impact of $\mathrm{N}$ excretion on the environment. J. Anim. Sci. 80:248-259.

Kucuk, O., B. W. Hess, P. A. Ludden, and D. C. Rule. 2001. Effect of forage:concentrate ratio on ruminal digestion and duodenal flow of fatty acids in ewes. J. Anim. Sci. 79:2233-2240.

Lemosquet, S., S. Rigout, A. Bach, H. Rulquin, and J. W. Blum. 2004. Glucose metabolism in lactating cows in response to isoenergetic infusions of propionic acid or duodenal glucose. J. Dairy Sci. 87:1767-1777

Loor, J. J., A. Ferlay, A. Oillier, M. Doreau, and Y. Chilliard. 2005. Relationship among trans and conjugated fatty acids and bovine milk fat yield due to dietary concentrate and linseed oil. J. Dairy Sci. 88:726-740.

Loor, J. J., K. Ueda, A. Ferlay, Y. Chilliard, and M. Doreau. 2004. Biohydrogenation, duodenal flow, and intestinal digestibility of trans fatty acids and conjugated linoleic acids in response to dietary forage:concentrate ratio and linseed oil in dairy cows. J. Dairy Sci. 87:2472-2485.

Lourenço, M., B. Vlaeminck, M. Bruinenberg, D. Demeyer, and V. Fievez. 2005. Milk fatty acid composition and associated rumen lipolysis and fatty acid hydrogenation when feeding forages from intensively managed or semi-natural grasslands. Anim. Res. $54: 471-484$.

Massart-Leën, A. M., E. Roets, G. Peeters, and R. Verbeke. 1983. Propionate for fatty acid synthesis by the mammary gland of the lactating goat. J. Dairy Sci. 66:1445-1454.

McGuire, M. A., J. M. Griinari, D. A. Dwyer, and D. E. Bauman. 1995. Role of insulin in the regulation of mammary synthesis of fat and protein. J. Dairy Sci. 78:816-824.

Minato, H., S. Ishibashi, and T. Hamaoka. 1988. Cellular fatty acid and sugar composition of representative strains of rumen bacteria. J. Gen. Appl. Microbiol. 34:303-319.
National Research Council. 2001. Nutrient Requirements of Dairy Cattle. 7th ed. Natl. Acad. Sci., Washington, DC.

Norma Portuguesa 1786. 1985. Alimentos para animais, determinação do teor de cálcio, método volumétrico, processo corrente. Diário da República, III Série de 09/07, no. 155. Lisbon, Portugal.

Norma Portuguesa 1785. 1986. Determinação do teor de açúcares. Diário da República, III Série de 30/05, no. 123. Lisbon, Portugal.

Norma Portuguesa 873. 1997. Alimentos para animais, determinação do teor de fósforo, método gravimétrico. Diário da República, III Série de 04/05, no. 103. Lisbon, Portugal.

O'Kelly, J. C., and W. G. Spiers. 1991. Influence of host diet on the concentrations of fatty acids in rumen bacteria from cattle. Aust. J. Agric. Res. 42:243-252.

Palmquist, D. L., A. D. Beaulieu, and D. M. Barbano. 1993. Feed and animal factors influencing milk fat composition. J. Dairy Sci. 76:1753-1771.

Palmquist, D. L., and T. C. Jenkins. 1980. Fat in lactation rations: Review. J. Dairy Sci. 63:1-14.

Rigout, S., C. Hurtaud, S. Lemosquet, A. Bach, and H. Rulquin. 2003. Lactational effect of propionic acid and duodenal glucose in cows. J. Dairy Sci. 86:243-253.

Robertson, J. B., and P. J. Van Soest. 1981. The detergent system of analysis and its application in human foods. Pages 123-158 in The Analysis of Dietary Fiber in Food. W. P. T. James, and O. Theander, ed. Marcel Dekker, New York, NY.

Rodriguez, L. A., C. C. Stallings, J. H. Herbein, and M. L. McGilliard. 1997. Effect of degradability of dietary protein and fat on ruminal, blood, and milk components of Jersey and Holstein cows. J. Dairy Sci. 80:353-363.

Rulquin, H., S. Rigout, S. Lemosquet, and A. Bach. 2004. Infusion of glucose directs circulating amino acids to the mammary gland in well-fed dairy cows. J. Dairy Sci. 87:340-349.

Salomonsson, A., A. Theander, and E. Westerlund. 1984. Chemical characterization of some Swedish cereal whole meal and bran fractions. Swedish J. Agric. Res. 14:111-117.

Scaife, J. R., K. W. J. Wahle, and G. A. Garton. 1978. Utilization of methylmalonate for the synthesis of branched-chain fatty acids by preparations of chicken liver and sheep adipose tissue. Biochem. J. 176:799-804.

Shingfield, K. J., C. K. Reynolds, B. Lupoli, V. Toivonen, M. P. Yurawecz, P. Delmonte, J. M. Griinari, A. S. Grandison, and D. E. Beever. 2005. Effect of forage type and proportion of concentrate in the diet on milk fatty acid composition in cows given sunflower oil and fish oil. Anim. Sci. 80:225-238.

Sukhija, P. S., and D. L. Palmquist. 1988. Rapid method for determination of total fatty-acid content and composition of feedstuffs and feces. J. Agric. Food Chem. 36:1202-1206.

Van Soest, P. J., J. B. Robertson, and B. A. Lewis. 1991. Symposium Carbohydrate methodology, metabolism, and nutritional implications in dairy cattle. Methods for dietary fiber, neutral detergent fiber, and nonstarch polysaccharides in relation to animal nutrition. J. Dairy Sci. 74:3583-3597.

Wang, Z., and L. A. Goonewardene. 2004. The use of mixed models in the analysis of animal experiments with repeated measures data. Can. J. Anim. Sci. 84:1-11.

Wongtangtintharn, S., H. Oku, H. Iwasaki, and T. Toda. 2004. Effect of branched-chain fatty acids on fatty acid biosynthesis of human breast cancer cells. J. Nutr. Sci. Vitaminol. (Tokyo) 50:137-143. 